Provided for non-commercial research and education use. Not for reproduction, distribution or commercial use.

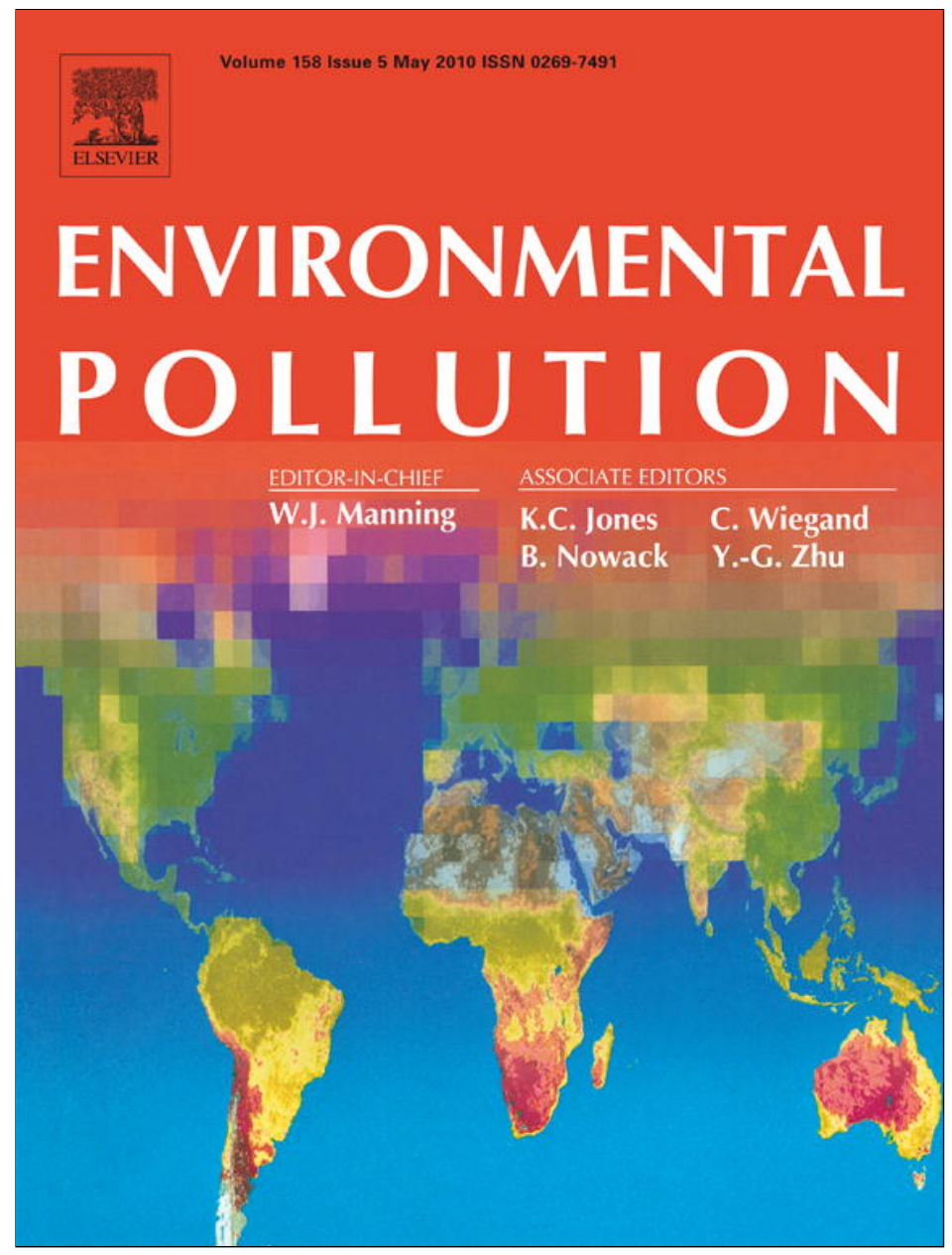

This article appeared in a journal published by Elsevier. The attached copy is furnished to the author for internal non-commercial research and education use, including for instruction at the authors institution and sharing with colleagues.

Other uses, including reproduction and distribution, or selling or licensing copies, or posting to personal, institutional or third party websites are prohibited.

In most cases authors are permitted to post their version of the article (e.g. in Word or Tex form) to their personal website or institutional repository. Authors requiring further information regarding Elsevier's archiving and manuscript policies are encouraged to visit:

http://www.elsevier.com/copyright 


\title{
Relationship between heavy metals pollution and genetic diversity in Mediterranean populations of the sandhopper Talitrus saltator (Montagu) (Crustacea, Amphipoda)
}

\author{
G. Ungherese ${ }^{\text {a }}$, A. Mengoni ${ }^{\text {a }}$, S. Somigli ${ }^{\text {a }}$, D. Baroni ${ }^{\text {b }}$, S. Focardi ${ }^{\text {b }}$, A. Ugolini $^{\text {a }, *}$ \\ a Dipartimento di Biologia Evoluzionistica “Leo Pardi”, Università degli studi di Firenze, Via Romana 17, 50125 Firenze, Italy \\ b Dipartimento di Scienze Ambientali “G. Sarfatti”, Università degli studi di Siena, Via Mattioli 4, 53100 Siena, Italy \\ Genetic variability of sandhoppers is affected by heavy metals contamination.
}

\section{A R T I C L E I N F O}

\section{Article history:}

Received 13 October 2009

Received in revised form

24 November 2009

Accepted 2 December 2009

\section{Keywords:}

Amphipods

Trace metals

Genetic variability

Bioaccumulation

Inter-Simple Sequence Repeats

\begin{abstract}
A B S T R A C T
Trace metals are one of the groups of pollutants that reduce genetic variability in natural populations causing the phenomenon known as "genetic erosion". In this study we evaluate the relationship between trace metals contamination $(\mathrm{Hg}, \mathrm{Cd}$ and $\mathrm{Cu}$ ) and genetic variability, assessed using fluorescent Inter-Simple Sequence Repeats (fISSRs). We used eight populations of a well-established biomonitor of trace metals on sandy beaches: the amphipod Talitrus saltator. The trace metals analysis confirmed the ability of sandhoppers to accumulate $\mathrm{Hg}, \mathrm{Cd}$ and $\mathrm{Cu}$. Moreover, populations from sites with high $\mathrm{Hg}$ availability had the lowest values of genetic diversity. Our results validate the use of fISSR markers in genetic studies in sandhoppers and support the "genetic erosion" hypothesis by showing the negative influence of $\mathrm{Hg}$ contamination on sandhopper genetic diversity. Therefore, genetic variability assessed with fISSR markers could be successfully employed as a biomarker of $\mathrm{Hg}$ exposure.
\end{abstract}

(C) 2009 Elsevier Ltd. All rights reserved.

\section{Introduction}

The genetic composition of natural populations is constantly modified by natural events (mutations, natural selection, stochastic processes and migrations). The evaluation of genetic diversity is especially important for species inhabiting transitional ecosystems, such as the supralittoral band of sandy shores, subjected to periodic and aperiodic changes in biotic and abiotic stress factors. Anthropogenic impact, such as pollution, can cause severe perturbations of the genetic structure. Understanding the effect of pollutants on genetic variability is fundamental in preserving the evolutionary potential of natural populations. Among the various groups of contaminants present in coastal areas, heavy metals seem to strongly affect genetic variability, both directly (via germ cell mutations) and indirectly (via somatic mutations or ecological and physiological effects) (Bickham et al., 2000; Belfiore and Anderson, 2001; De Wolf et al., 2004). By favoring more tolerant genotypes and causing demographic bottlenecks, trace metals exposure can alter the genetic composition of a population, leading to a decrease of genetic variability known as "genetic erosion" (Van Straalen and Timmermans, 2002).

\footnotetext{
* Corresponding author. Tel.: +39055 2288219; fax: +39 0552288565 .

E-mail address: alberto.ugolini@unifi.it (A. Ugolini).
}

Talitrid amphipods, one of the main components (in terms of biomass) of the supralittoral of sandy beaches, play an important role in the energy flow within the sandy beach ecosystem because they feed on organic matter of marine and terrestrial origin and provide nourishment for many species of beetles, fishes, birds and mammals (e.g. see Griffiths et al., 1983). The sandhopper Talitrus saltator is a well-established biomonitor of trace metals contamination, since studies carried out on the Baltic coast of Poland (Rainbow et al., 1998; Fialkowski et al., 2000, 2009), on the U.K. coast (Moore and Rainbow, 1987; Rainbow et al., 1989; Moore et al., 1991) and on Mediterranean shores (Ugolini et al., 2004, 2005, 2008) have demonstrated that $T$. saltator accumulates trace metals (mainly $\mathrm{Cu}, \mathrm{Cd}, \mathrm{Hg}, \mathrm{Zn}, \mathrm{Mn}, \mathrm{Al}, \mathrm{Fe}$ and $\mathrm{Ni}$ ).

Despite the importance of the species, little is known about the genetic structure of $T$. saltator populations, especially at the microgeographical scale where cycles of extinction and colonization may be frequent and detailed knowledge of population diversity and structure could be crucial for risk assessment of beach ecosystems. Previous studies have reported data on large-scale geographical variation in the whole Mediterranean basin (De Matthaeis et al., 1995, 1998, 2000; Scapini et al., 1999). They showed a high level of genetic variation and a pattern of genetic differentiation between populations fitting the isolation-by-distance model (De Matthaeis et al., 2000). However, it is unclear how the described patterns are 
applicable on a small geographical scale, i.e. how predictable is it that populations of T. saltator living in close proximity will exchange alleles.

To date, no molecular markers have been developed for analyses of T. saltator population genetics. Due to the low variability, the use of allozyme patterns has little use when high-resolution studies, such as those performed at the micro-geographical scale, have to be performed. Inter-Simple Sequence Repeats (ISSRs) are molecular markers with high resolving power at the population level which do not need prior molecular knowledge of the organisms (e.g. genome sequence, microsatellites, etc.); they also allow a large number of samples to be analyzed thanks to the possibility of automation by the use of fluorescently labeled primers and capillary electrophoresis in an automated sequencer (fISSR, Nagaraju et al., 2002). ISSR markers have been widely used in plants for germplasm characterization and population genetics studies (see for instance Semagn et al., 2006; He et al., 2007), and their use is now extending to animal population studies (e.g. Wink, 2006; Pazza et al., 2007; Machkour-M'Rabet et al., 2009) and taxon and cell line identification (e.g. Maltagliati et al., 2006; Tan et al., 2006).

In this study we evaluated the effects of three accumulated trace metals with high toxicity and harm for biological systems and human health $(\mathrm{Hg}, \mathrm{Cu}$ and $\mathrm{Cd})$ on the genetic variability of Mediterranean populations of $T$. saltator, assessed using fluorescent ISSR markers. Since previous research has shown that genetic variability in $T$. saltator seems to vary according to shoreline stability (Ketmaier et al., 2003; Scapini et al., 2005), we also took this factor into account.

\section{Materials and methods}

\subsection{Collection of samples}

Eight populations of T. saltator were collected in June 2008 along the Tyrrhenian coast of central Italy (Fig. 1), from $10^{\circ} 16^{\prime} 31^{\prime \prime} \mathrm{E}$ latitude to $11^{\circ} 11^{\prime} 41^{\prime \prime} \mathrm{E}$ latitude, at sites with different degrees of trace metals contamination (Ugolini et al., 2004) and

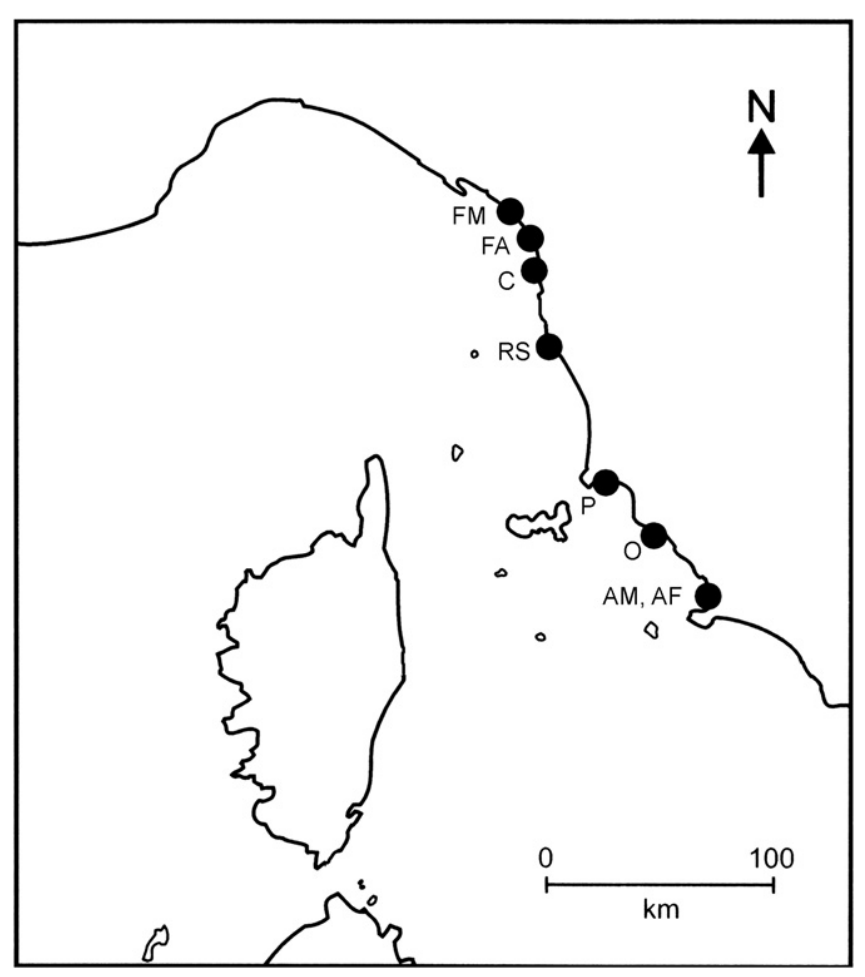

Fig. 1. Map of the Tyrrhenian coast of central Italy showing the sites where populations were collected. coastal stability (Albani et al., 1940; Ferretti et al., 2003; Rossi et al., 2008) (Table 1). Adult individuals (except for ovigerous female) were collected, transported alive to the laboratory and stored frozen at $-80^{\circ} \mathrm{C}$ prior to DNA extraction and trace metals analysis. Since size can influence the amount of accumulated metals (Marsden and Rainbow, 2004) in amphipods, only individuals of similar weight (0.015-0.02 g) were used for $\mathrm{Hg}, \mathrm{Cd}$ and $\mathrm{Cu}$ analysis. At each sampling site, a sample of sand was collected in the zone frequented by the sandhoppers during the day and analyzed for trace metals contamination.

\subsection{DNA extraction and fluorescent ISSR amplification}

DNA was extracted from animals stored at $-80^{\circ} \mathrm{C}$ using a NucleoSpin Tissue kit (Macherey-Nagel). Single animals were washed in physiological solution to eliminate sand and residual material from the legs, ground in sterile $1.5 \mathrm{ml}$ polypropylene tubes with sterile Teflon pestles and then subjected to DNA extraction according to the kit manufacturer's instructions. DNA was quantified by spectrophotometric readings (Biophotometer, Eppendorf) and gel electrophoresis after ethidium bromide staining.

ISSR amplification was carried out in a total volume of $25 \mu \mathrm{L}$ containing $10 \mathrm{ng}$ of template DNA, 2 U of Taq DNA polymerase (GoTaq, Promega), 10 pmol of fluorescently labeled ISSR primer, $0.2 \mathrm{mM}$ of each dNTP, $1.5 \mathrm{mM} \mathrm{MgCl}_{2}$ and $1 \times$ concentration of Taq DNA polymerase buffer (GoTaq, Promega). Cycling conditions were as follows: $5 \mathrm{~min} 95^{\circ} \mathrm{C}$, followed by 40 cycles composed of $20 \mathrm{~s} 95^{\circ} \mathrm{C}, 30 \mathrm{~s}$ $66^{\circ} \mathrm{C}-1{ }^{\circ} \mathrm{C} /$ cycle for the first 10 cycles and then $55{ }^{\circ} \mathrm{C}, 2$ min $72{ }^{\circ} \mathrm{C}$ and a final extension step of $5 \mathrm{~min} 72{ }^{\circ} \mathrm{C}$. Amplification products from all 130 animals were resolved by capillary electrophoresis on an Applied Biosystems ABI PRISM ${ }^{\circledR} 3100$ Automated Capillary Genetic Analyzer (Applied Biosystems, Foster City, CA, USA) using GenScan ROX 2500 (Applied Biosystems) as size standard. Fifteen animals from different populations were amplified twice to establish the reproducibility and background noise cut-off.

\subsection{Trace metals analysis}

The samples of sand and sandhoppers were dehydrated at $40{ }^{\circ} \mathrm{C}$ until constant weight (minimum $0.5 \mathrm{~g}$ dry weight) and then finely ground. Around $150 \mathrm{mg}$ of each sample were mineralized in Teflon vessels containing $3 \mathrm{ml}$ of $\mathrm{HNO}_{3}$ at $120^{\circ} \mathrm{C}$ for $8 \mathrm{~h}$. After digestion, the solution was brought to a volume of $10 \mathrm{ml}$ by addition of deionized water. During each mineralization, several "blank trials" were performed to verify the absence of contamination.

The analyses of metal contents were performed by atomic absorption spectrometry. $\mathrm{Cd}$ and $\mathrm{Cu}$ were determined by atomization with a graphite furnace and Zeeman background corrector, while the FIMS (Flow Injection Mercury System) was used for $\mathrm{Hg}$. Each analysis was carried out three times and the accuracy of the analytical procedures was assessed by comparing the results of contemporary digestions and analyses of Standard Reference Materials (SRMs): SRM 1566 "oyster tissue" from the National Institute of Standards and Technology (NIST, Gaithersburg, USA). The results of the determinations were only accepted if the values measured for the SRMs were within the certified concentration range. The element concentrations (expressed as $\mu \mathrm{g} / \mathrm{g}$ ) were calculated by the method of "internal additions". The coefficients of variation for the elements analyzed were between $5 \%$ and $10 \%$.

\subsection{Data analysis}

The bioaccumulation of each metal in T. saltator was investigated by comparing the sand and sandhopper concentrations by means of the Sign test (Siegel and Castellan, 1989).

For the ISSR data, chromatogram files from automated sequencer sizing were imported into GeneMarker ver. 1.71 software (SoftGenetics LLC, State College, PA, USA) by filtering with the default options of the module for AFLP analysis. The cut-off values (200 fluorescence units for background noise and size range from 100 to $2000 \mathrm{nt}$ ) were set after analysis of replicate samples, taking into account only bands

Table 1

Main features and genetic diversity of the analyzed populations. Population name, code, number of animals analyzed and geographical coordinates are shown. See text for further explanations.

\begin{tabular}{llllll}
\hline Population name & Code & $\begin{array}{l}\text { No. of } \\
\text { animals }\end{array}$ & Longitude & Latitude & $\begin{array}{l}\text { Coastal } \\
\text { stability }\end{array}$ \\
\hline Morto Vecchio river & FM & 16 & $43^{\circ} 44^{\prime} 55^{\prime \prime} \mathrm{N}$ & $10^{\circ} 16^{\prime} 31^{\prime \prime} \mathrm{E}$ & Stable \\
Arno river & FA & 18 & $43^{\circ} 40^{\prime} 55^{\prime \prime} \mathrm{N}$ & $10^{\circ} 16^{\prime} 52^{\prime \prime} \mathrm{E}$ & Unstable \\
Calambrone & $\mathrm{C}$ & 18 & $43^{\circ} 34^{\prime} 56^{\prime \prime} \mathrm{N}$ & $10^{\circ} 17^{\prime} 56^{\prime \prime} \mathrm{E}$ & Unstable \\
Rosignano Solvay & $\mathrm{RS}$ & 14 & $43^{\circ} 22^{\prime} 24^{\prime \prime} \mathrm{N}$ & $10^{\circ} 26^{\prime} 23^{\prime \prime} \mathrm{E}$ & Unstable \\
Piombino & $\mathrm{P}$ & 17 & $42^{\circ} 57^{\prime} 07^{\prime \prime} \mathrm{N}$ & $10^{\circ} 34^{\prime} 11^{\prime \prime} \mathrm{E}$ & Stable \\
Ombrone river & $\mathrm{O}$ & 16 & $42^{\circ} 39^{\prime} 30^{\prime \prime} \mathrm{N}$ & $11^{\circ} 00^{\prime} 50^{\prime \prime} \mathrm{E}$ & Unstable \\
Albegna beach & $\mathrm{AM}$ & 10 & $42^{\circ} 30^{\prime} 36^{\prime \prime} \mathrm{N}$ & $11^{\circ} 11^{\prime} 30^{\prime \prime} \mathrm{E}$ & Unstable \\
Albegna river & $\mathrm{AF}$ & 14 & $42^{\circ} 30^{\prime} 16^{\prime \prime} \mathrm{N}$ & $11^{\circ} 11^{\prime} 41^{\prime \prime} \mathrm{E}$ & Stable \\
\hline
\end{tabular}


present in duplicate reactions from 15 test animals. Consequently, only peaks with the above-mentioned characteristics were considered for profile analysis of the whole dataset of 130 animals. Statistical analyses were performed on a binary matrix produced by linearly combining the results of different primers, assigning $1 / 0$ values to band presence/absence. A matrix of genetic similarity between animals was computed with NTSYS-pc ver. 2.02 (Rohlf, 1990) based on presence/absence of bands, using Jaccard's coefficient of similarity. Unlike Lynch and Milligan's parameters for dominant markers (Lynch and Milligan, 1994), Jaccard's coefficient takes into account only band presence sharing between individuals and is commonly used for the analysis of markers treated as dominant, such as ISSRs (Lowe et al., 2004).

Within-population genetic variation was computed as "mean number of pairwise differences" and "average gene diversity over loci" using Arlequin 3.11 software (http://cmpg.unibe.ch/software/arlequin3/). Analysis of Molecular Variance (AMOVA) (Excoffier et al., 1992) as implemented in Arlequin 3.11 was used to analyze the partition of total genetic variation at three hierarchical levels: within populations, between populations and between groups of populations. The statistical significance was computed by a permutation test after 10000 random permutations. The Bayesian clustering method for dominant markers, implemented by a Markov chain Monte Carlo algorithm present in Structure 2.2 (Pritchard et al. 2000; Falush et al., 2007), was also used to identify the population structure. Data were obtained with runs of 100000 iterations (three times for each $K$-value) and a burning of 20000 iterations.

Genetic distances between populations were estimated by computing a matrix of pairwise $F_{S T}$ values (Slatkin, 1995) which was then used to infer a NeighborJoining dendrogram with MEGA4 software (Tamura et al., 2007). The significance of pairwise $F_{S T}$ values was computed by a permutation test after 1000 random permutations.

Pairwise $F_{S T}$ values were compared with the linear and log-transformed geographical distances between populations according to Mantel's test (Mantel, 1967) as implemented in NTSYS-pc ver. 2.02 (Rohlf, 1990); normalized Mantel $Z$ statistics were calculated after 1000 permutations.

The Spearman rank-order correlation coefficient test (Siegel and Castellan, 1989) was used to establish if there were relationships between trace metals pollution and genetic variability and between stability of the coastal environment and genetic variability.

\section{Results}

\subsection{Trace metals accumulation}

Fig. 2 and Table 2 show that the concentrations of $\mathrm{Hg}, \mathrm{Cd}$ and $\mathrm{Cu}$ in amphipod tissues were generally higher than those in the sand ( $n=8, x=1, p=0.035$ for $\mathrm{Hg}, n=8, x=0, p=0.004$ for $\mathrm{Cu}$ and $\mathrm{Cd}$ ).

\subsection{ISSR fingerprinting}

Ten primers [ISSR\#1: HVH(TTC $)_{4}$; ISSR\#2: YG(CA) $)_{9}$; ISSR\#3: (CA $)_{7}$; ISSR\#4; (CA $)_{7} \mathrm{RY}$; ISSR\#5: RY(CA $)_{7}$; ISSR\#6: V(CT) ${ }_{8} \mathrm{D}$; ISSR\#7: $\mathrm{B}(\mathrm{GA})_{5} \mathrm{H}$; ISSR\#8: (TGA) $)_{5}$; ISSR\#9: YG(GA) $)_{9}$; ISSR\#10: YG(CT) $)_{9}$ ] were initially screened for the presence of amplification products, reproducibility, readability and pattern polymorphism in DNA of two animals from different populations. Two of the primers (ISSR\#5 and ISSR\#9) gave the most successful results and were used for the analysis of all samples. These two primers produced 54 polymorphic bands (markers) ranging from 242 to 1014 bp for ISSR\#9 (46 markers) and from 369 to 581 bp for ISSR\#5 (8 markers). In total, 504 bands were retrieved in 130 animals. Each animal showed an average of $3.77 \pm 1.16$ markers.

\subsection{Genetic diversity}

The variation of within-population genetic diversity was quite high (Table 2), ranging from 4.30 (mean number of pairwise differences) of population FM to 6.89 of population AF. Only two markers were present in all populations (public alleles), 40 were distributed in 2-6 populations, while 12 were restricted to one population only (private alleles). The distribution of private markers among populations is also reported in Table 2. Four populations did not show private alleles (AM, FM, O, RS), while the others showed one or two private alleles.
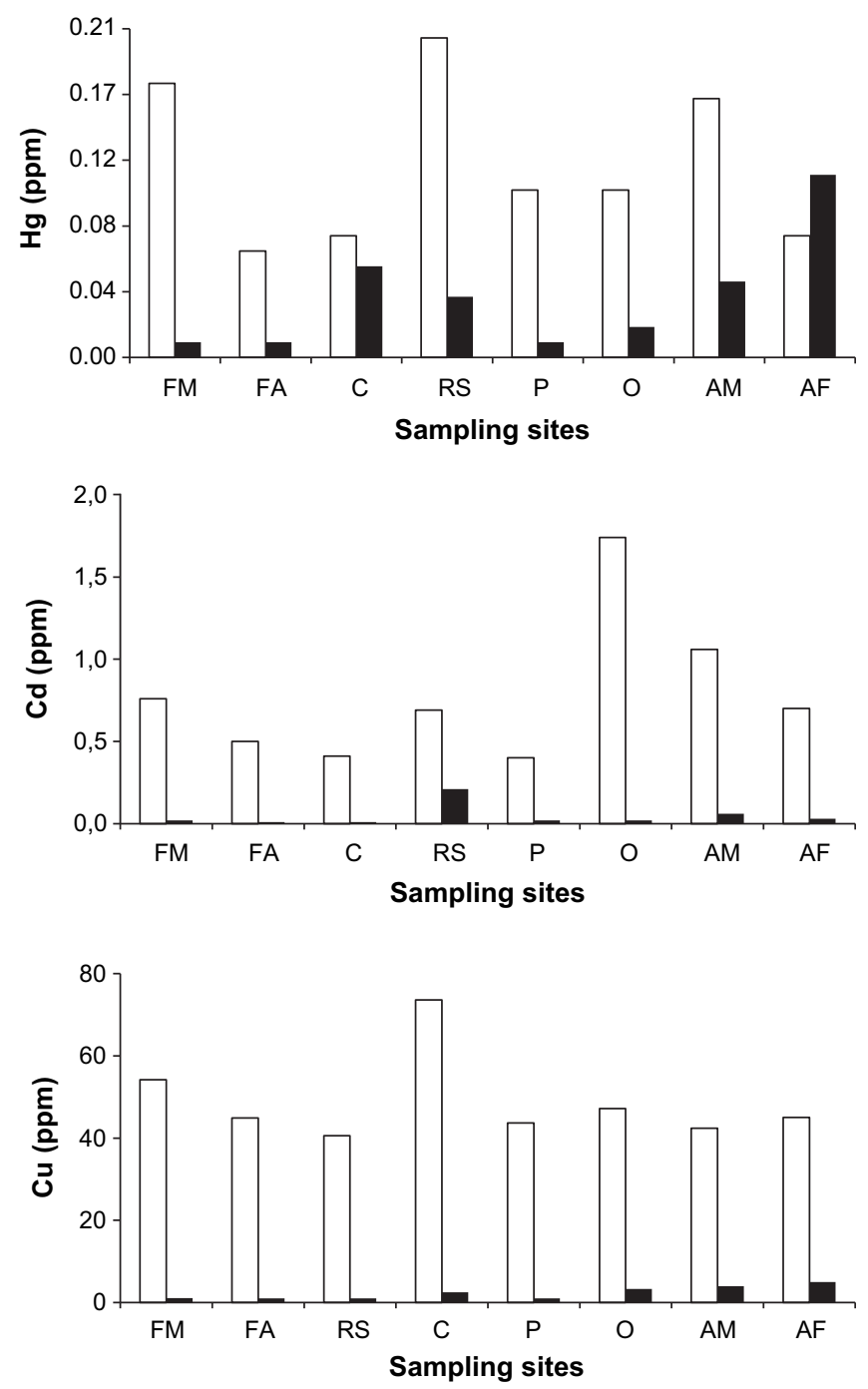

Fig. 2. Trace metals concentrations (ppm) in the sand (black bars) and in the sandhoppers (white bars). For each element, sampling sites are ordered according to the latitude. For further explanations, see Fig. 1 and Table 1.

\subsection{Hierarchical structure of genetic variation}

AMOVA (Table 3 ) showed that the genetic differentiation among populations was relatively high $\left(F_{S T}=0.165\right)$. The greatest proportion of the total variation in our sample $(83.45 \%)$ was due to intra-

Table 2

Genetic diversity of analyzed populations, estimated as "average gene diversity over loci" and "mean number of pairwise differences"; Npm: number of private markers. $\mathrm{Hg}, \mathrm{Cd}$ and $\mathrm{Cu}$ concentration in sandhoppers is also shown. For further explanations, see Table 1 and text.

\begin{tabular}{|c|c|c|c|c|c|c|}
\hline \multirow[t]{2}{*}{$\begin{array}{l}\text { Population } \\
\text { code }\end{array}$} & \multicolumn{2}{|l|}{ Genetic diversity } & \multirow[t]{2}{*}{ Npm } & \multicolumn{3}{|c|}{$\begin{array}{l}\text { Metals } \\
\text { concentration } \\
(\mathrm{ppm})\end{array}$} \\
\hline & $\begin{array}{l}\text { Mean number of } \\
\text { pairwise differences }\end{array}$ & $\begin{array}{l}\text { Average gene } \\
\text { diversity over loci }\end{array}$ & & $\mathrm{Hg}$ & $\mathrm{Cd}$ & $\mathrm{Cu}$ \\
\hline FM & 4.30 & 0.0796 & 0 & 0.18 & 0.76 & 54.2 \\
\hline FA & 5.75 & 0.1065 & 1 & 0.07 & 0.50 & 44.9 \\
\hline C & 5.41 & 0.1000 & 2 & 0.08 & 0.41 & 73.6 \\
\hline RS & 4.83 & 0.089 & 0 & 0.21 & 0.69 & 40.6 \\
\hline $\mathrm{P}$ & 6.11 & 0.1132 & 2 & 0.11 & 0.40 & 43.7 \\
\hline 0 & 5.40 & 0.1001 & 0 & 0.11 & 1.74 & 47.2 \\
\hline AM & 4.33 & 0.0802 & 0 & 0.17 & 0.70 & 42.4 \\
\hline $\mathrm{AF}$ & 6.89 & 0.1275 & 2 & 0.08 & 1.06 & 45.0 \\
\hline
\end{tabular}


Table 3

Analysis of molecular variance (AMOVA) in 123 individuals from eight $T$. saltator populations: a) overall; b) and c) geographical partition with different groupings. ${ }^{a}$

\begin{tabular}{lrrrrl}
\hline Source of variation & d.f. & $\begin{array}{l}\text { Sum of } \\
\text { squares }\end{array}$ & Variance & \% Total & P \\
\hline a) Overall & 7 & 76.749 & 0.53848 & 16.55 & $<0.0001$ \\
Among populations & 115 & 312.357 & 2.71615 & 83.45 & $<0.0001$ \\
Within populations & 122 & 389.106 & 3.25463 & & \\
Total & & & & & \\
& 4 & 63.693 & 0.51342 & 15.39 & $<0.008$ \\
b) Five groups partition & 3 & 13.056 & 0.10604 & 3.18 & $<0.0001$ \\
Among groups & 115 & 312.357 & 2.71615 & 81.43 & $<0.0001$ \\
Among populations/groups & 122 & 389.106 & 3.33560 & & \\
Within populations & & & & & \\
Total & 5 & 70.157 & 0.58480 & 17.54 & $<0.02$ \\
& 2 & 6.592 & 0.03350 & 1.00 & $<0.0001$ \\
c) Six groups partition & 115 & 312.357 & 2.71615 & 81.46 & $<0.0001$ \\
Among groups & 122 & 389.106 & 3.33445 & & \\
Among populations/groups & & & & \\
Within populations & & & & \\
Total & & & & & \\
\hline
\end{tabular}

${ }^{a}$ The AMOVA was performed attributing the following two types of geographical groupings: b) north-south gradient with five groups (FM, FA, C); (RS); (P), (O); (AM, $\mathrm{AF})$; c) north-south gradient with six groups (FM, FA, C); (RS); (P), (O); (AM); (AF). For each grouping, the percentage of total variance observed was attributed to two or three hierarchical partitions: among groups; among populations within groups; among single individuals within populations. Data show the degrees of freedom (d.f.), the sum of squared deviation, the variance component estimate, the percentage of total variance contributed by each component and the probability of obtaining a more extreme component estimate by chance alone (P). $p$-values were estimated by computing 10000 permutations.

population differences, rather than to among-population differences (16.55\%). The geographical differentiation of populations was also tested. The partition of populations into five and six groups gave the highest among-group variance components (also with significant $p$-values). Moreover, the Bayesian inference of population structure performed with Structure 2.2 gave similar results, with maximal Ln-likelihood at $K=5(-1191.4)$.

\subsection{Genetic differentiation between populations}

The Neighbor-Joining dendrogram of populations based on pairwise $F_{S T}$ (Fig. 3a) showed a well-structured pattern of genetic distances. Two main clusters could be recognized within the

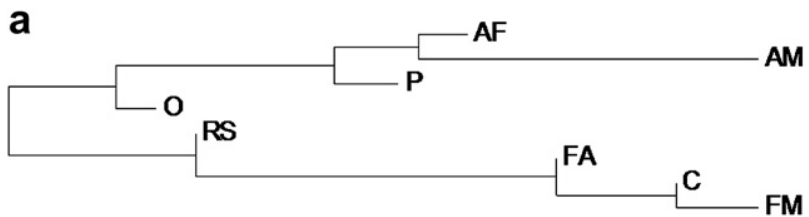

0.02
b \begin{tabular}{|l|l|l|l|l|l|l|l|l|}
\hline & AF & AM & C & FA & FM & O & P & RS \\
\hline AF & 0.000 & & & & & & & \\
\hline AM & 0.093 & 0.000 & & & & & & \\
\hline C & 0.255 & 0.000 & 0.000 & & & & & \\
\hline FA & 0.246 & 0.255 & 0.026 & 0.000 & & & & \\
\hline FM & 0.307 & 0.000 & 0.002 & 0.016 & 0.000 & & & \\
\hline O & 0.107 & 0.145 & 0.178 & 0.152 & 0.204 & 0.000 & & \\
\hline P & 0.033 & 0.131 & 0.247 & 0.233 & 0.291 & 0.079 & 0.000 & \\
\hline RS & 0.158 & 0.222 & 0.075 & 0.078 & 0.000 & 0.074 & 0.104 & 0.000 \\
\hline
\end{tabular}

Fig. 3. Genetic differentiation between populations. a) Neighbor-joining dendrogram; b) pairwise $F_{S T}$ (values in bold indicate non-significant values at $p<0.05$ ).
T. saltator group: populations $\mathrm{P}, \mathrm{AM}, \mathrm{AF}$ and populations O, RS, FA, C, $\mathrm{FM}$, corresponding to the southern and northern groups of localities indicated in Fig. 1. This subdivision was statistically well supported and accounted for $15.1 \%$ of the variation (as computed with AMOVA, $p<0.04$ ). Within the cluster corresponding to the northern populations, the most similar ones (C, FM and FA) formed a tight sub-cluster. Since there was no statistical support for the pairwise $F_{S T}$ values between them (Fig. $3 \mathrm{~b}$ ), it can be assumed that these three populations form a unique group with no differentiation among them. In contrast, there are significant pairwise $F_{S T}$ values between all three populations (P, AM, AF) in the southern cluster, supporting their genetic differentiation.

To test for a geographically-based distribution of genetic diversity, we carried out Mantel's test of correlation between genetic and geographical distances. The results indicated a high level of correlation with both linear $(r=0.805 ; p<0.005)$ and log-transformed $(r=0.640 ; p<0.007)$ geographical distances.

\subsection{Trace metals accumulation and genetic diversity}

Among all the metals analyzed, only $\mathrm{Hg}$ showed a significant correlation between metal concentration and genetic variability of populations ( $r_{\mathrm{s}}=-0.74$, d.f. $=7, p<0.05$ ) (Fig. 4). In fact, the sandhoppers collected from the sampling sites with the highest $\mathrm{Hg}$ levels ( $\mathrm{RS}=0.21 \mathrm{ppm}, \mathrm{FM}=0.18 \mathrm{ppm}, \mathrm{AM}=0.17 \mathrm{ppm}$, Fig. 4 ) had the lowest levels of genetic variability (Table 2). There was no significant correlation between genetic diversity and metal concentration for $\mathrm{Cd}$ and $\mathrm{Cu}\left(r_{\mathrm{s}}=-0.54\right.$, d.f. $=7, p=\mathrm{N}$. S. for $\mathrm{Cd}$; $r_{\mathrm{s}}=-0.02$, d.f. $=7, p=$ N.S. for Cu) (Fig. 4 ).

\subsection{Coastal stability and genetic diversity}

The sampling sites were divided into "stable" and "unstable" based on data recorded from late 1800 (Albani et al., 1940) to 2008 (Ferretti et al., 2003; Rossi et al., 2008). The Spearman rank-order correlation test did not show a significant correlation between coastal stability and genetic variability $\left(r_{\mathrm{s}}=-0.28\right.$, d.f. $=7, p=$ N.S.).

\section{Discussion}

The results of our trace metals analysis agree with previous data regarding the Tuscan coast (Ugolini et al., 2004, 2008) and confirm the ability of sandhoppers to accumulate $\mathrm{Hg}, \mathrm{Cd}$ and $\mathrm{Cu}$ showing differences among sampling sites (see Marsden and Rainbow, 2004 for a review).

The developed markers, based on two primers having a $(\mathrm{CA})_{7}$ and a (GA) 9 repeat motif (ISSR\#5 and ISSR\#9, respectively), resulted in 54 highly polymorphic markers which produced 502 alleles (bands) in 130 animals. In spite of the narrow geographical range, the analysis of private markers revealed that populations AF, P, C, FA present unique alleles, suggesting that the gene flow between populations is quite low or that several bottlenecks, with reduction in effective population size followed by rapid expansion, could have taken place. In this view, the mismatched distribution for populations AF, P and FA (data not shown) approximates a bimodal curve, which could support the hypothesis of bottlenecks for those populations. However, an analysis with other markers (e.g. co-dominant microsatellites) is needed to resolve this issue. Genetic diversity values varied relatively little. However, populations with no private alleles tended to have lower values of genetic diversity; in particular, populations RS and AM showed some of the lowest genetic diversity values. Populations with the lowest diversity values also inhabited sites heavily contaminated by $\mathrm{Hg}$, and there was a significant negative correlation between $\mathrm{Hg}$ concentration and genetic variability of populations. Exposure to 

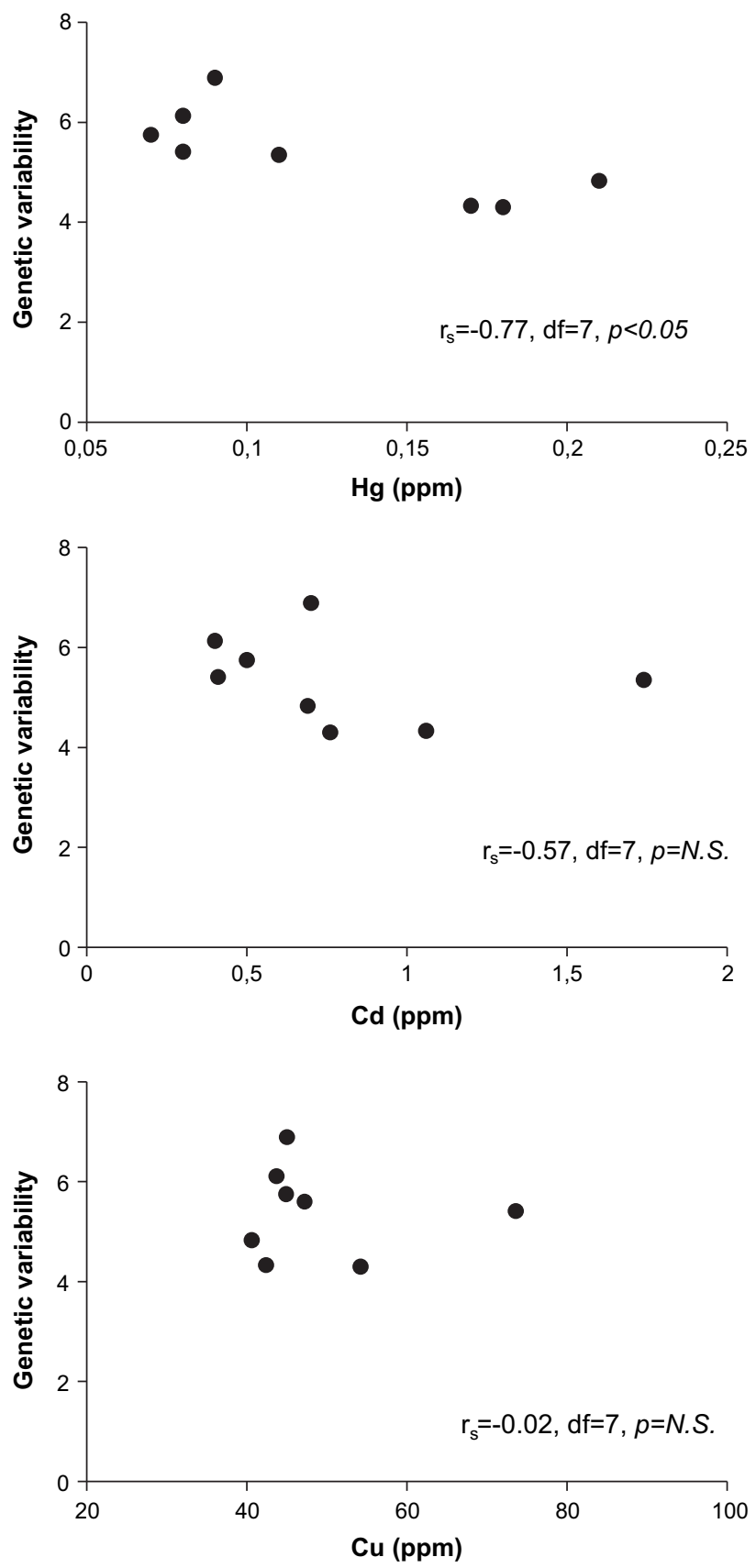

Fig. 4. Relationship between trace metals concentrations in tissues of $T$. saltator (expressed in ppm) and genetic variability (expressed as mean number of pairwise differences). For each metal the value of Spearman rank-order correlation coefficient test $\left(r_{\mathrm{s}}\right)$, degrees of freedom $(\mathrm{df})$ and probability $(p)$ are given. For further explanations see also Table 2 .

genotoxic chemicals such as $\mathrm{Hg}$ can act as a selective force, eliminating sensitive genotypes within a population with predictable changes in genetic variability in affected populations. Results of other studies support the correlation between $\mathrm{Hg}$ exposure and genetic diversity. Populations of the sunfish Lepomis auritus from $\mathrm{Hg}$-contaminated rivers showed differences in genetic distances with respect to unexposed populations (Nadig et al., 1998). Individuals of the marine gastropod Monodonta turbinata from $\mathrm{Hg}$-contaminated areas had high amounts of Hg-tolerant allozymes with respect to animals sampled in uncontaminated areas (Nevo et al., 1984). Our findings seem to confirm the important role of $\mathrm{Hg}$ contamination as a selective force in contaminated populations.
$\mathrm{Hg}$ contamination in the most polluted localities is well documented. RS is located near the Solvay chemical plant (built in 1918) whose effluents, characterized by high levels of $\mathrm{Hg}$, discharge directly into the sea (Ferrara et al., 1989). AM is affected by the cinnabar (HgS) geological anomaly on Mt. Amiata and in particular by the $\mathrm{Hg}$ mining conducted from the Etruscan period (8th - 1st century B.C.) to 1980 (Barghigiani et al., 1996).

The high sensitivity of $\mathrm{T}$. saltator to $\mathrm{Hg}$ contamination is also supported by the $\mathrm{LC}_{50}$ data reported by Ungherese and Ugolini (2009). For this species, $\mathrm{Hg}$ is more toxic than $\mathrm{Cu}$ and $\mathrm{Cd}$, with wide differences in the $\mathrm{LC}_{50}$ values: $0.02 \mathrm{ppm}$ for $\mathrm{Hg}, 13.28$ for $\mathrm{Cu}$ and 27.66 for Cd (Ungherese and Ugolini, 2009). Therefore, although we cannot exclude the influence of other pollutants, $\mathrm{Hg}$ seems to have an important role in the reduction of genetic variability in T. saltator. Moreover, on the Tuscan coast, genetic erosion has recently been detected in the littoral crab Pachygrapsus marmoratus from sites with different degrees of $\mathrm{As}, \mathrm{Cd}, \mathrm{Pb}$ and $\mathrm{Cu}$ contamination (Fratini et al., 2008). Our analyses did not reveal a correlation between coastal stability and genetic diversity, as proposed by other authors (Ketmaier et al., 2003; Scapini et al., 2005). Therefore, contrary to the results of these authors, trace metals contamination (particularly $\mathrm{Hg}$ ) rather than coastal stability seems to have a negative influence on the genetic diversity of T. saltator populations.

The gene flow between $T$. saltator populations was then investigated by analysis of the population structures. We found a good correlation between geographical distance and genetic distance between populations, in agreement with an isolation-by-distance model as previously proposed for this species over a larger geographical range (De Matthaeis et al., 2000). Moreover, we found structuring of populations in a northern and a southern group. In the latter, there was unexpected differentiation, even at a very small scale (AM-AF, about $600 \mathrm{~m}$ apart). Sympatric differentiation in tidal and estuarine animals due to behavioral and ecological causes has already been detected (Stanhope et al., 1992; Bilton et al., 2002; Vesakoski et al., 2009). However, further investigations into the eco-ethology and physiology of these two populations are necessary to fully understand the basis of the quasi-sympatric differentiation. In the northern Tuscany populations (FM, FA, C), only the last one (C) was differentiated from the others, revealing higher gene flow between northern populations than between southern ones. This suggests that local conditions have a high impact on the $T$. saltator population structure and may strongly influence gene flow between sites, even at a very small scale.

\section{Conclusions}

Talitrid amphipods such as the sandhopper T. saltator are wellestablished biomonitors of trace metals contamination. Despite their recognized role as bioindicators of human impact on sandy beaches, no molecular markers have been developed to allow rapid and high-throughput screening of genetic diversity in talitrids. We applied fluorescent Inter-Simple Sequence Repeats (fISSRs) to T. saltator, aiming to investigate the genetic diversity and structure of eight populations inhabiting the Tyrrhenian (western) coast of central Italy and their relationships with trace metal contents $(\mathrm{Hg}$, $\mathrm{Cd}, \mathrm{Cu}$ ). This study demonstrates the usefulness of fISSR markers in investigations of $T$. saltator population genetics. Indeed, these markers reveal differences among populations despite the small geographical range.

Our results also support the "genetic erosion" hypothesis (Van Straalen and Timmermans, 2002) and highlight the role of $\mathrm{Hg}$ pollution in the reduction of population genetic diversity. The $\mathrm{Hg}$ concentrations in the sandhopper tissues were negatively correlated to the genetic variability. Coastal stability seems not to affect the genetic variability of sandhoppers. Therefore, genetic differences 
assessed with fISSR markers could be used as valid biomarkers to detect $\mathrm{Hg}$ exposure in $\mathrm{T}$. saltator and could be used to identify coastal areas where $\mathrm{Hg}$ contamination is particularly strong.

\section{Acknowledgments}

The research was financially supported by the Fondazione Monte dei Paschi (Siena) (grants 31017 and 33798 assigned to A. Ugolini). We are grateful to F. Luzzi for technical assistance with DNA manipulation. Thanks are due to the Ente Parco Regionale di Migliarino, San Rossore, Massaciuccoli (Pisa) for authorizing the sampling.

\section{References}

Albani, D., Griselli, A., Mori, A., 1940. Le spiagge toscane. Consiglio Nazionale delle Ricerche, Roma.

Arlequin ver. 3.11. An Integrated Software for Population Genetics Data Analysis. http://cmpg.unibe.ch/software/arlequin3/.

Barghigiani, C., Ristori, T., Lopez Arenas, J., 1996. Mercury in marine sediments from a contaminated area of the northern Tyrrhenian sea: $<20 \mu \mathrm{m}$ grain-size fraction and total sample analysis. Sci. Total Environ. 192, 63-73.

Belfiore, N.N., Anderson, S.L., 2001. Effects of contaminants on genetic patterns in aquatic organisms: a review. Mutat. Res. 489, 97-122.

Bickham, J.W., Sandhu, S., Herbert, P.D.N., Chikhi, L., Athwal, R., 2000. Effects of chemical contaminants on genetic diversity in natural populations: implications for biomonitoring and ecotoxicology. Mutat. Res. 463, 33-51.

Bilton, D.T., Paula, J., Bishop, J.D.D., 2002. Dispersal, genetic differentiation and speciation in estuarine organisms. Estuar. Coast. Shelf Sci. 55, 937-952.

De Matthaeis, E., Cobolli, M., Mattoccia, M., Scapini, F., 1995. Geographic variation in Talitrus saltator (Crustacea, Amphipoda) - biochemical evidence. Boll. Zool. 62, $77-84$

De Matthaeis, E., Davolos, D., Cobolli, M., 1998. Genetic divergence between populations and species of talitrids from Aegean Islands. J. Hered. 89, 37-43.

De Matthaeis, E., Davolos, D., Cobolli, M., Ketmaier, V., 2000. Isolation by distance in equilibrium and nonequilibrium populations of four talitrid species in the Mediterranean Sea. Evolution 54, 1606-1613.

De Wolf, H., Blust, R., Backeljau, T., 2004. The population genetic structure of Littorina littorea (Mollusca: Gastropoda) along a pollution gradient in the Scheldt estuary (The Netherlands) using RAPD analysis. Sci. Total Environ. 325, 59-69.

Excoffier, L., Smouse, P.E., Quattro, M., 1992. Analysis of molecular variance inferred from metric distances among DNA haplotypes: application to human mitochondrial DNA restriction data. Genetics 131, 479-491.

Falush, D., Stephens, M., Pritchard, J.K., 2007. Inference of population structure using multilocus genotype data: dominant markers and null alleles. Mol. Ecol. Notes 7, 574-578.

Ferrara, R., Maserti, E., Paterno, P., 1989. Mercury distribution in maritime sediments and its correlation with the Posidonia oceanica prairie in a coastal area affected by a chlor-alkali complex. Toxicol. Environ. Chem. 22, 131-134.

Ferretti, O., Delbono, I., Furia, S., Barsanti, M. (Eds.), 2003. Elementi di gestione costiera. Parte Seconda. Erosione costiera. Lo stato dei litorali italiani Rapporto Tecnico ENEA RT/2003/43/CLIM.

Fialkowski, W., Calosi, P., Dahlke, S., Dietrich, A., Moore, P.G., Olenin, S., Persson, L.E., Smith, B.D., Špegys, M., Rainbow, P.S., 2009. The sandhopper Talitrus saltator (Crustacea: Amphipoda) as biomonitor of trace metals bioavailability in European coastal waters. Mar. Pollut. Bull. 58, 39-44.

Fialkowski, W., Rainbow, P.S., Fialkowska, E., Smith, B.D., 2000. Biomonitoring of trace metals along the Baltic Coast of Poland using the sandhopper Talitrus saltator (Montagu) (Crustacea: Amphipoda). Ophelia 52, 183-192.

Fratini, S., Zane, L., Ragionieri, L., Vannini, M., Cannicci, S., 2008. Relationship between heavy metal accumulation and genetic variability decrease in the intertidal crab Pachygrapsus marmoratus (Decapoda; Grapsidae). Estuar. Coast. Shelf Sci. 79, 679-686.

Griffiths, C.L., Stenton-Dozey, J.M.E., Koop, K., 1983. Kelp wrack and the flow of energy through a sandy beach ecosystem. In: McLachlan, A., Erasmus, T. (Eds.), Sandy Beaches as Ecosystems. Dr. W. Junk Publishers, The Hague, pp. 547-556.

He, F., Kang, D., Ren, Y., Qu, L.J., Zhen, Y., Gu, H., 2007. Genetic diversity of the natural populations of Arabidopsis thaliana in China. Heredity 99, 423-431.

Ketmaier, V., Scapini, F., De Matthaeis, E., 2003. Exploratory analysis of talitrid population genetics as an indicator of the quality of sandy beaches. Estuar. Coast. Shelf Sci. 58, 159-167.

Lowe, A., Harris, S., Ashton, P., 2004. Ecological Genetics. Design, Analysis, and Application. Blackwell, Oxford.
Lynch, M., Milligan, B.G., 1994. Analysis of population genetic structure with RAPD markers. Mol. Ecol. 3, 91-99.

Machkour-M'Rabet, S., Hénaut, Y., Dor, A., Pérez-Lachaud, G., Pélissier, C., Gers, C., Legal, L., 2009. ISSR (Inter Simple Sequence Repeats) as molecular markers to study genetic diversity in tarantulas (Araneae, Mygalomorphae). J. Arachnol. 37, $10-14$.

Maltagliati, F., Lai, T., Casu, M., Valdesalici, S., Castelli, A., 2006. Identification of endangered Mediterranean cyprinodontiform fish by means of DNA intersimple sequence repeats (ISSRs). Biochem. Syst. Ecol. 34, 626-634.

Mantel, N., 1967. The detection of disease clustering and a generalized regression approach. Cancer Res. 27, 209-220.

Marsden, I.D., Rainbow, P.S., 2004. Does the accumulation of trace metals in crustaceans affect their ecology - the amphipod example? J. Exp. Mar. Biol. Ecol. 300, 373-408

Moore, P.G., Rainbow, P.S., 1987. Copper and zinc in an ecological series of talitroidean Amphipoda (Crustacea). Oecologia 73, 120-126

Moore, P.G., Rainbow, P.S., Hayes, E., 1991. The beach-hopper Orchestia gammarellus (Crustacea: Amphipoda) as a biomonitor for copper and zinc: North Sea trials. Sci. Total Environ. 106, 221-228.

Nadig, S.G., Lee, K.L., Adams, S.M., 1998. Evaluating alterations of genetic diversity in sunfish populations exposed to contaminants using RAPD. Aquat. Toxicol. 43, 163-178.

Nagaraju, J., Kathirvel, M., Subbaiah, E.V., Muthulakshmi, M., Kumar, L.D., 2002. FISSR-PCR: a simple and sensitive assay for high throughput genotyping and genetic mapping. Mol. Cell. Probes 16, 67-72.

Nevo, E., Ben-Schlomo, R., Lavie, B., 1984. Mercury selection of allozymes in marine organisms: prediction and verification in nature. Proc. Natl. Acad. Sci. U.S.A. 81, 1258-1259.

Pazza, R., Kavalco, K.F., Prioli, S., Prioli, A.J., Bertollo, L.A.C., 2007. Chromosome polymorphism in Astyanax fasciatus (Teleostei, Characidae), part 3: analysis of the RAPD and ISSR molecular markers. Biochem. Syst. Ecol. 35, 843-851.

Pritchard, J.K., Stephens, M., Donnelly, P., 2000. Inference of population structure using multilocus genotype data. Genetics 155, 945-959.

Rainbow, P.S., Fialkowski, W., Smith, B.D., 1998. The sandhopper Talitrus saltator as a trace metal biomonitor in the Gulf of Gdansk, Poland. Mar. Pollut. Bull. 36, 193-200.

Rainbow, P.S., Moore, P.G., Watson, D., 1989. Talitrid amphipods (Crustacea) as biomonitors for copper and zinc. Estuar. Coast. Shelf Sci. 28, 567-582.

Rohlf, F.J., 1990. NTSYS-pc. Numerical Taxonomy and Multivariate Analysis System. Version 2.02. Exeter Software, New York.

Rossi, S., Querci, P., Giovannoni, G., Mastri, R. (Eds.), 2008. Relazione sullo stato dell'ambiente in Toscana 2008 ARPAT-Regione Toscana, Edifir-Edizioni Firenze.

Scapini, F., Campacci, F., Audoglio, M., 1999. Variation among natural populations of Talitrus saltator (Amphipoda): Morphometric analysis. Crustaceana 72, 659-672.

Scapini, F. Chelazzi, L. Colombini, I, Fallaci, M. Fanini, L, 2005. Orientation of sandhoppers at different points along a dynamic shoreline in southern Tuscany. Mar. Biol. 147, 919-926.

Semagn, K., Bjornstad, A., Ndjiondjop, M.N., 2006. An overview of molecular marker methods for plants. Afr. J. Biotechnol. 5, 2540-2568.

Siegel, S., Castellan, J.J.N., 1989. Nonparametric Statistics for the Behavioral Sciences, second ed. McGraw Hill, New York.

Slatkin, M., 1995. A measure of population subdivision based on microsatellite allele frequencies. Genetics 139, 457-462.

Stanhope, M.J., Leighton, B.J., Hartwick, B., 1992. Polygenic control of habitat preference and its possible role in sympatric population subdivision in an estuarine crustacean. Heredity 69, 279-288.

Tamura, K., Dudley, J., Nei, M., Kumar, S., 2007. MEGA4: Molecular Evolutionary Genetics Analysis (MEGA) software version 4.0. Mol. Biol. Evol. 24, 1596-1599.

Tan, G.L., Chu, Y.M., Chen, J.B., Li, H.Q., 2006. Genomic instability in the progression of sporadic nasopharyngeal carcinoma. Otolar. Head Neck Surg. 134, 147-152.

Ugolini, A., Borghini, F., Calosi, P., Bazzicalupo, M., Chelazzi, G., Focardi, S., 2004. Mediterranean Talitrus saltator (Crustacea, Amphipoda) as a biomonitor of heavy metals contamination. Mar. Pollut. Bull. 48, 526-532.

Ugolini, A., Borghini, F., Focardi, S., Chelazzi, G., 2005. Heavy metals accumulation in two syntopic sandhopper species: Talitrus saltator (Montagu) and Talorchestia ugolinii (Bellan Santini and Ruffo). Mar. Pollut. Bull. 50, 1328-1334.

Ugolini, A., Ungherese, G., Somigli, S., Galanti, G., Baroni, D., Borghini, F., Cipriani, N., Nebbiai, M., Passaponti, M., Focardi, S., 2008. The amphipod Talitrus saltator as a bioindicator of human trampling on sandy beaches. Mar. Environ. Res. 65, 349-357.

Ungherese, G., Ugolini, A., 2009. Sandhoppers solar orientation as a behavioural biomarker of trace metals contamination. Environ. Pollut. 175, 1360-1364.

Van Straalen, N.M., Timmermans, M.J.T.N., 2002. Genetic variation in toxicantstressed populations: an evaluation of the "genetic erosion" hypothesis. Hum. Ecol. Risk Assess. 8, 983-1002.

Vesakoski, O., Rautanen, J., Jormalainen, V., Ramsay, T., 2009. Divergence in host use ability of a marine herbivore from two habitat types. J. Evol. Biol. 22, $1545-1555$.

Wink, M., 2006. Use of DNA markers to study bird migration. J. Ornithol. 147, $234-244$. 